\title{
RANCANG BANGUN SISTEM INFORMASI HONORARIUM MENGAJAR DOSEN
}

\author{
Wiyata \\ Program Studi Ilmu Administrasi Bisnis, Bidang Ilmu Manajemen Sistem Informasi, \\ Fakultas Ilmu Administrasi, Universitas Brawijaya \\ E-mail : wiyata@ub.ac.id
}

(Naskah masuk : 18 Februari 2016, diterima untuk diterbitkan : 17 Maret 2016)

\begin{abstract}
Abstrak
Honorarium merupakan salah satu unsur penting pendorong motivasi dosen dalam pelaksanaan kegiatan Tri Dharma Perguruan Tinggi khususnya bidang pelaksanaan pendidikan oleh karena itu perlu dikelola dengan sistem database yang terintegrasi. Penelitian ini bertujuan merancang dan membangun sistem informasi untuk peningkatan efisiensi, transparansi, akurasi dalam pengelolaan honorarium mengajar dosen. Identifikasi kebutuhan pengguna dan sistem dilakukan melalui interview dan observasi cara kerja pengelolaan honorarium mengajar dosen di bagian akademik dan bagian keuangan. Model pengembangan sistem dalam penelitian ini menggunakan metode Prototyping. Hasil pengujian menggunakan Metode Response Time, Accuracy Testing, dan Black Box Testing menunjukkan bahwa Sistem Informasi Honorarium Mengajar Dosen (SI-HMD) yang dikembangkan telah berfungsi sesuai dengan kebutuhan fungsional dan operasional yang diharapkan.
\end{abstract}

Kata Kunci : honorarium mengajar dosen, rancang bangun sistem informasi

\begin{abstract}
Honorarium is an important element for boosting lecturer's motivation in the implementation of Tri Dharma University particularly in the field of education implementation therefore it needs to be managed with an integrated database system. The purpose of this research is to design and build information system for improving the efficiency, transparancy, and accuracy of the management of lecturer's teaching honorarium. Identifying user needs and system requirements was carried out by interview and observation on how the management of honorarium for the lecturers in the academic and financial devision. System development model in this research used prototyping method. The test results using Response Time, Accurate Testing, Black Box Testing Methods indicated that the developed Information System of Lecturer's Teaching Honorarium (IS-LTH) has been functioning in accordance with the expected functional and operational requirements.
\end{abstract}

Keywords : lecturer's teaching honorarium, design and build information system

\section{PENDAhuluan}

Honorarium mengajar merupakan salah satu unsur penting pendorong motivasi dosen dalam pelaksanaan kegiatan Tri Dharma Perguruan Tinggi khususnya bidang pelaksanaan pendidikan. Hal ini menuntut Perguruan Tinggi meningkatkan kualitas pelayanan kepada dosen dengan melakukan pengelolaan honorarium mengajar secara efektif dan efisien agar dapat menunjang kelancaran proses belajar mengajar serta menciptakan suasana akademik yang kondusif. Sampai saat ini Perguruan Tinggi XYZ masih menggunakan sistem manual dalam pengolalaan honorarium mengajar dosen.

Beberapa permasalahan yang biasa terjadi pada sistem manual antara lain; (1) proses presensi dan rekapitulasi kehadiran tidak efisien, (2) kurang transparan karena dosen tidak dapat mengakses informasi honorarium yang akan diterima dosen, dan (3) hasil perhitungan honorarium tidak akurat sehingga sering menimbulkan perselisihan antara dosen dan bagian keuangan. Bertitik tolak dari permasalahan tersebut maka perlu dibangun sistem informasi yang dapat berfungsi meningkatkan efisiensi, transparansi, dan akurasi dalam pengelolaan honorarium mengajar dosen.

Pengembangan sistem dalam penelitian ini menggunakan teknologi fingerprint dan pemrograman Visual Basic untuk input kehadiran, sedangkan untuk proses rekapitulasi kehadiran, perhitungan dan pelaporan honorarium menggunakan menggunakan PHP dan database MySQL. Teknologi Fingerprint adalah perangkat elektronik yang berfungsi sebagai pemindai sidik jari. Sidik jari banyak dipergunakan untuk mendeteksi kehadiran pegawai karena memiliki beberapa sifat antara lain :

1. Guratan-guratan sidik jari melekat pada kulit manusia seumur hidup.

2. Sidik jari tidak pernah berubah kecuali mengalami kecelakaan serius.

3. Sulit dipalsukan atau dimanipulasi karena setiap orang memiliki pola sidik jari yang unik dan berbeda. 
Sistem pengenal sidik jari (fingerprint) miliki beberapa keunggulan antara lain :

1. Sangat Praktis

Sistem pengenal sidik jari sangat praktis penggunaanya untuk mendeteksi kehadiran.

2. Akurasi Tinggi

Sistem pengenal sidik jari memiliki tingkat akurasi cukup tinggi.

3. Sekuritas Tinggi

Sistem pengenal sidik jari relatif lebih aman karena sulit dimanipulasi.

4. Ekonomis

Sistem pengenal sidik jari relatif lebih ekonomis dibandingkan sistem pengenal lainnya seperti Radio Frequency Identification (RFID).

5. Skalabilitas tinggi

Sistem pengenal sidik jari memiliki kapasitas penyimpanan data hingga ribuan record.

6. Terintegrasi

Sistem pengenal sidik jari memiliki software bawaan yang berfungsi mengatur interkoneksi antara mesin fingerprint dengan database.

Cara kerja scanner fingerprint adalah dengan mengambil gambar sidik jari, memproses secara digital, dan memverifikasi apakah guratan sidik jari dari gambar yang diambil sama dengan pola sidik jari yang ada di database.

Dalam pengembangan SI-HMD ini pembacaan data fingerprint menggunakan OCX ZKemKeeper 6.0 Control bawaan (bult-in) dari mesin fingerprint kemudian hasil dari pembacaan dikonversi menjadi data access, selanjutnya data tersebut diintegrasikan dengan Database MySQL yang ada di Server melalui Open Database Connectivity (ODBC)

\section{METODOLOGI}

Penelitian ini menggunakan metode prototyping untuk membangun sistem informasi honorarium mengajar dosen. Prototyping adalah proses membangun sistem eksperimental secara cepat dan tidak mahal. Proses interaksi dengan prototipe memungkinkan pengguna mendapatkan ide yang lebih baik untuk menentukan kebutuhan informasi. Berikut langkah-langkah yang digunakan dalam metode pengembangan sistem prototyping :

1. Identified basic requirements

Perancang sistem bekerja dengan pengguna secara intensif untuk mengidentifikasi kebutuhan dasar informasi bagi pengguna.

2. Develop a working prototype

Perancang sistem mendesain prototipe secara cepat dengan memanfaatkan computer aided software engineering (CASE).

3. Use the prototype

Pengguna didorong untuk bekerja dengan sistem untuk menentukan apakah prototipe yang dibangun telah sesuai dengan kebutuhan pengguna.

4. Revise and enhance the protype
Pengembang sistem mencatat semua perubahan permintaan pengguna dan menyempurnakan prototipe.

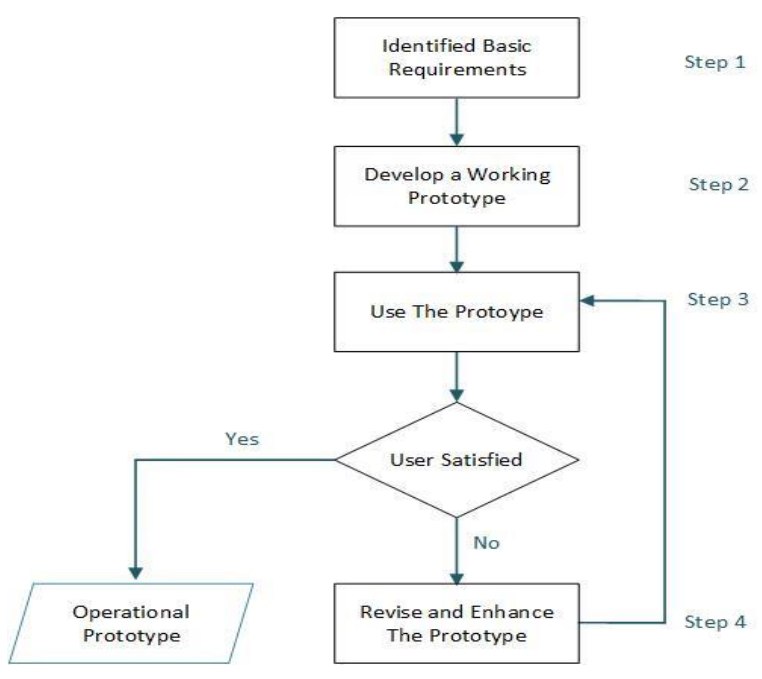

Gambar 1. Metode Prototyping

\section{HASIL DAN PEMBAHASAN}

\subsection{Identifikasi Kebutuhan Pengguna dan Sistem}

Hasil interview dan observasi cara kerja di bagian akademik dan keuangan pada Perguruan Tinggi XYZ diperoleh fakta bahwa sistem presensi mengajar dosen dilakukan secara manual dengan mencatat dan membubuhkan tanda tangan di daftar kehadiran dosen. Kemudian menjelang akhir bulan petugas akademik menyusun rekapitulasi kehadiran dosen menggunakan MS. Excel selanjutnya diserahkan ke bagian keuangan untuk proses penghitungan honorarium mengajar dan pencetakan slip pembayaran.

Berdasarkan kondisi existing tersebut dapat diidentifikasi beberapa kebutuhan pengguna (user requirements) sebagai berikut:

1. Bagian akademik membutuhkan sistem presensi mengajar dosen yang cepat, aman, dan efisien.

2. Bagian akademik membutuhkan sistem yang memudahkan dan mempercepat proses rekapitulasi kehadiran.

3. Bagian keuangan membutuhkan sistem yang dapat meningkatkan kecepatan dan akurasi proses penghitungan honorarium mengajar dosen.

Sedangkan kebutuhan sistem (system requirements) teridentifikasi sebagai berikut :

1. Sistem diharapkan dapat meningkatkan transparansi dalam pengelolaan honorarium dengan memberi hak akses kepada dosen untuk mendapatkan informasi besaran honorarium mengajar dosen yang akan diterima.

Sistem harus mengakomodir kebijakan pimpinan Perguruan Tinggi XYZ yang menerapkan sistem perhitungan honorarium berdasarkan kelebihan jam mengajar atas beban kerja normal dosen 
Jurnal Teknologi Informasi dan Ilmu Komputer (JTIIK)

Vol. 3, No. 1, Maret 2016, hlm. 35-42

yaitu 6 SKS sesuai Surat Edaran Menteri Keuangan Nomor : S-168/MK.02/2014 tentang Standar Biaya Umum di lingkungan Perguruan Tinggi. Secara matematis honorarium kelebihan mengajar dosen dirumuskan sebagai berikut :

$\mathrm{Hr}=\sum$ hadir $* \sum \mathrm{SKS}_{\text {lebih }} *$ Tarif

dimana :

$\mathrm{Hr}=$ besaran honor mengajar per bulan

$\sum$ hadir $=$ jumlah kehadiran

$\sum \mathrm{SKS}_{\text {lebih }}=\mathrm{jumlah}$ sks yang diampu-6sks

Tarif $=$ tarif honor per bulan per sks

\subsection{Rancangan Arsitektur Sistem}

Mekanisme kerja SI-HMD dimulai dengan melakukan registrasi sidik jari dosen untuk pencatatan kedalam database. Selanjutnya sesuai jadwal kuliah yang telah ditetapkan setiap dosen sebelum masuk kelas untuk mengajar terlebih dahulu melakukan presensi melalui fingerprint tersebut. Sistem secara otomatis akan merekam dan merekap jumlah kehadiran serta menghitung honorarium yang akan diterima oleh masing-masing dosen sehingga dosen, ketua jurusan, wakil dekan II dapat mengakses laporan jumlah kehadiran dan laporan honorarium mengajar yang akan diterima.

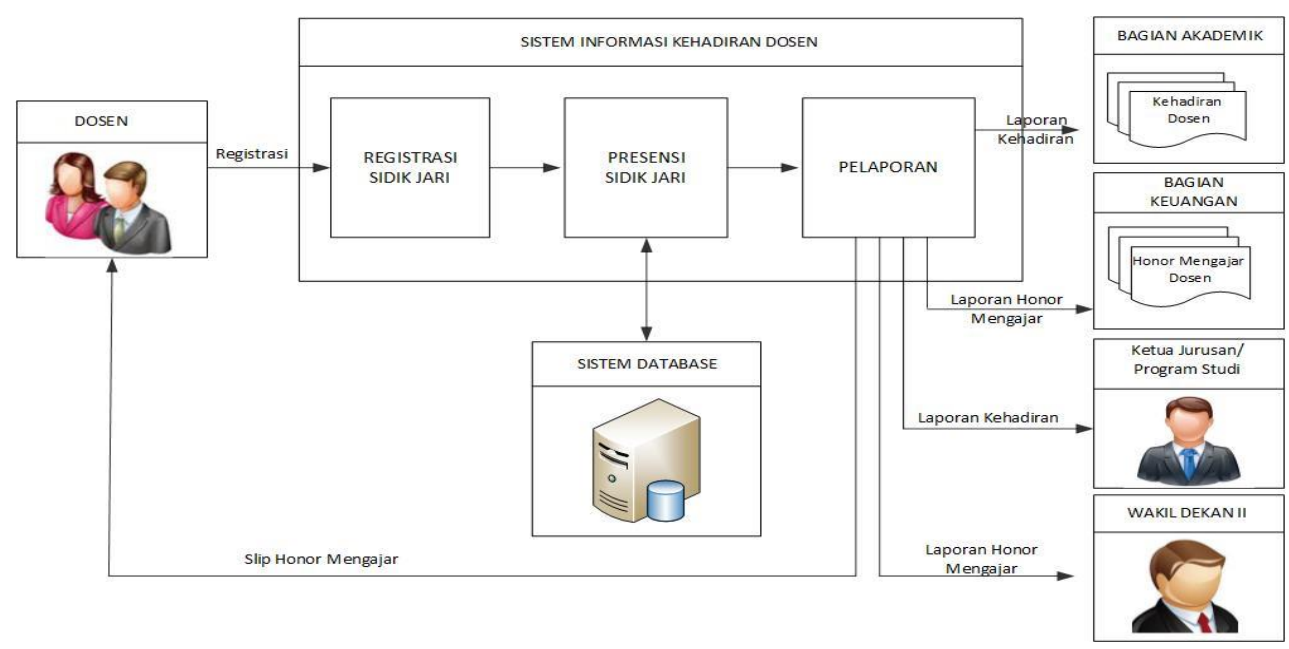

Gambar 2. Rancangan Arsitektur Sistem

\subsection{Rancangan Use Case}

Use case adalah representasi sederhana yang menunjukkan interaksi antara pengguna (actor) dan kasus penggunaan (use case) dalam suatu sistem. Use case berguna untuk membuat model bisnis proses berdasarkan presepektif pengguna. Actor merepresentasikan orang yang mengoperasikan atau berinteraksi dengan sistem. Use case dilambangkan berbentuk elips dengan label nama operasi di dalamnya. Gambar di bawah ini adalah diagram use case SI-HMD yang akan dibangun.

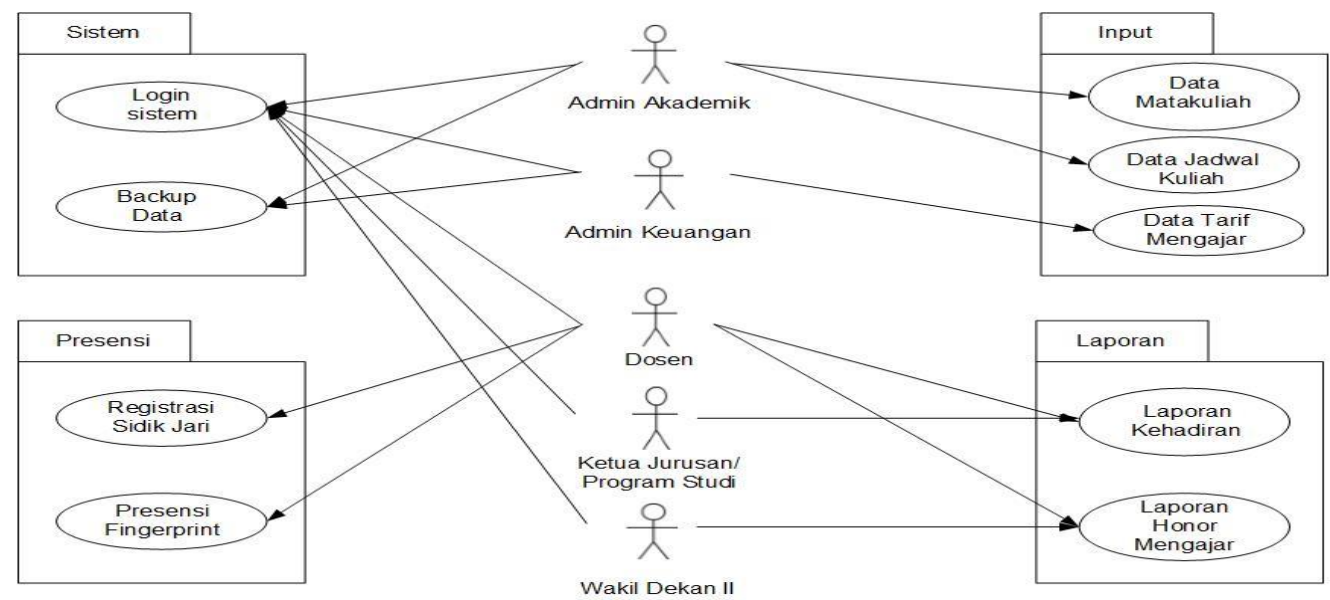

Gambar 3. Diagram Use Case 
38 Jurnal Teknologi Informasi dan Ilmu Komputer (JTIIK), Vol. 3, No. 1, Maret 2016, hlm. 35-42

Tabel 1. Keterangan Aktor

\begin{tabular}{|c|l|l|}
\hline No. & \multicolumn{1}{|c|}{ Aktor } & \multicolumn{1}{|c|}{ Keterangan } \\
\hline 1 & Dosen & $\begin{array}{l}\text { User yang memiliki hak } \\
\text { akses untuk registrasi dan } \\
\text { presensi fingerprint. }\end{array}$ \\
\hline 2 & $\begin{array}{l}\text { Admin } \\
\text { Akademik }\end{array}$ & $\begin{array}{l}\text { Operator yang bertugas } \\
\text { menginputkan biodata } \\
\text { dosen, data matakuliah, } \\
\text { dan jadwal kuliah. }\end{array}$ \\
\hline 3 & $\begin{array}{l}\text { Admin } \\
\text { Keuangan }\end{array}$ & $\begin{array}{l}\text { Operator yang bertugas } \\
\text { menginputkan data tarif } \\
\text { mengajar dan menerima } \\
\text { laporan honor mengajar. }\end{array}$ \\
\hline 4 & $\begin{array}{l}\text { Ketua Jurusan } \\
\text { /Program Studi }\end{array}$ & $\begin{array}{l}\text { User yang memiliki } \\
\text { wewenang menerima } \\
\text { laporan kehadiran dosen. }\end{array}$ \\
\hline 5 & Wakil Dekan II & $\begin{array}{l}\text { User yang memiliki } \\
\text { wewenang menerima } \\
\text { laporan honorarium } \\
\text { mengajar. }\end{array}$ \\
\hline
\end{tabular}

\subsection{Rancangan Database}

\section{Diagram Konteks}

Diagram konteks merupakan diagram untuk menggambarkan sistem secara umum. Entitas yang terhubung dengan SI-HMD antara lain dosen, ketua jurusan, wakil dekan II, bagian akademik, dan bagian keuangan. Masukan dari entitas dosen ke sistem yaitu biodata, sidik-jari dan presensi, keluaran dari sistem ke ketua jurusan berupa laporan presensi dosen sedangkan keluaran ke wakil dekan II berupa laporan honorarium mengajar dosen.
Tabel 2. Keterangan Use Case

\begin{tabular}{|c|c|c|}
\hline No. & Use Case & Keterangan \\
\hline 1 & Login Sistem & $\begin{array}{l}\text { Memberikan hak akses } \\
\text { kepada aktor yang diberi } \\
\text { kewenangan. }\end{array}$ \\
\hline 2 & $\begin{array}{l}\text { Input Biodata } \\
\text { Dosen }\end{array}$ & $\begin{array}{l}\text { Admin akademik } \\
\text { memasukkan biodata } \\
\text { dosen. }\end{array}$ \\
\hline 3 & $\begin{array}{l}\text { Input Data } \\
\text { Matakuliah }\end{array}$ & $\begin{array}{l}\text { Admin akademik } \\
\text { memasukkan data } \\
\text { matakuliah. }\end{array}$ \\
\hline 4 & $\begin{array}{l}\text { Input Data } \\
\text { Jadwal } \\
\text { Kuliah }\end{array}$ & $\begin{array}{l}\text { Admin akademik } \\
\text { memasukkan jadwal } \\
\text { kuliah. }\end{array}$ \\
\hline 5 & $\begin{array}{l}\text { Input Tarif } \\
\text { Mengajar }\end{array}$ & $\begin{array}{l}\text { Admin keuangan } \\
\text { memasukkan data tarif } \\
\text { mengajar. }\end{array}$ \\
\hline 6 & $\begin{array}{l}\text { Registrasi } \\
\text { Sidik Jari }\end{array}$ & $\begin{array}{l}\text { Admin akademik } \\
\text { mendaftarkan sidik jari } \\
\text { semua dosen. }\end{array}$ \\
\hline 7 & $\begin{array}{l}\text { Presensi } \\
\text { Fingerprint }\end{array}$ & $\begin{array}{l}\text { Dosen melalukan presensi } \\
\text { mengajar menggunakan } \\
\text { fingerprint. }\end{array}$ \\
\hline 8 & $\begin{array}{l}\text { Laporan } \\
\text { Kehadiran } \\
\text { Mengajar }\end{array}$ & $\begin{array}{l}\text { Dosen dan Ketua } \\
\text { Jurusan/Program Studi } \\
\text { menerima laporan } \\
\text { kehadiran mengajar }\end{array}$ \\
\hline 9 & $\begin{array}{l}\text { Laporan } \\
\text { Honor } \\
\text { Mengajar }\end{array}$ & $\begin{array}{l}\text { Admin keuangan dan } \\
\text { Wakil Dekan II menerima } \\
\text { laporan honorarium } \\
\text { mengajar. }\end{array}$ \\
\hline
\end{tabular}

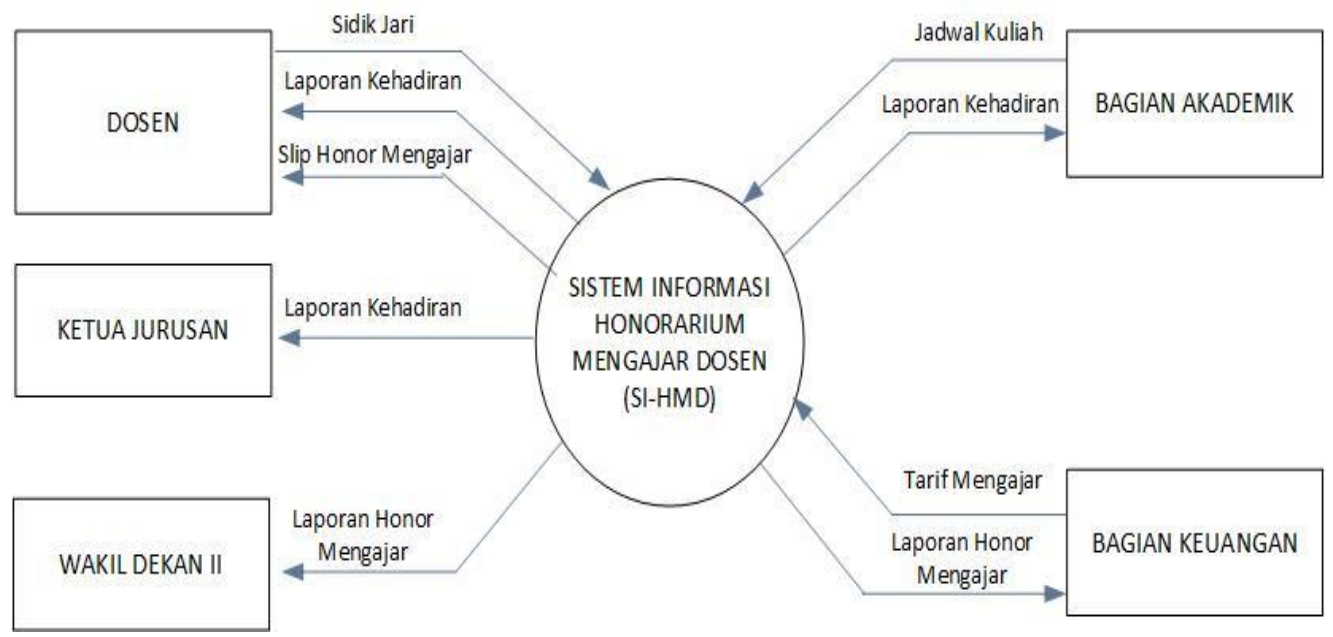

Gambar 4. Diagram Konteks 


\section{DFD Level Nol}

DFD Level Nol adalah gambaran aliran data dari mulai dari input data dasar, kemudian diproses oleh sistem, hingga menjadi laporan. Alur data secara keseluruhan pada SI-HMD dimulai dari memasukkan data sidik jari dosen, biodata dosen dan data jadwal kuliah dari bagian akademik, dan data tarif mengajar dari bagian keuangan, selanjutnya diproses hingga menghasilkan laporan presensi kehadiran dan honorarium mengajar.

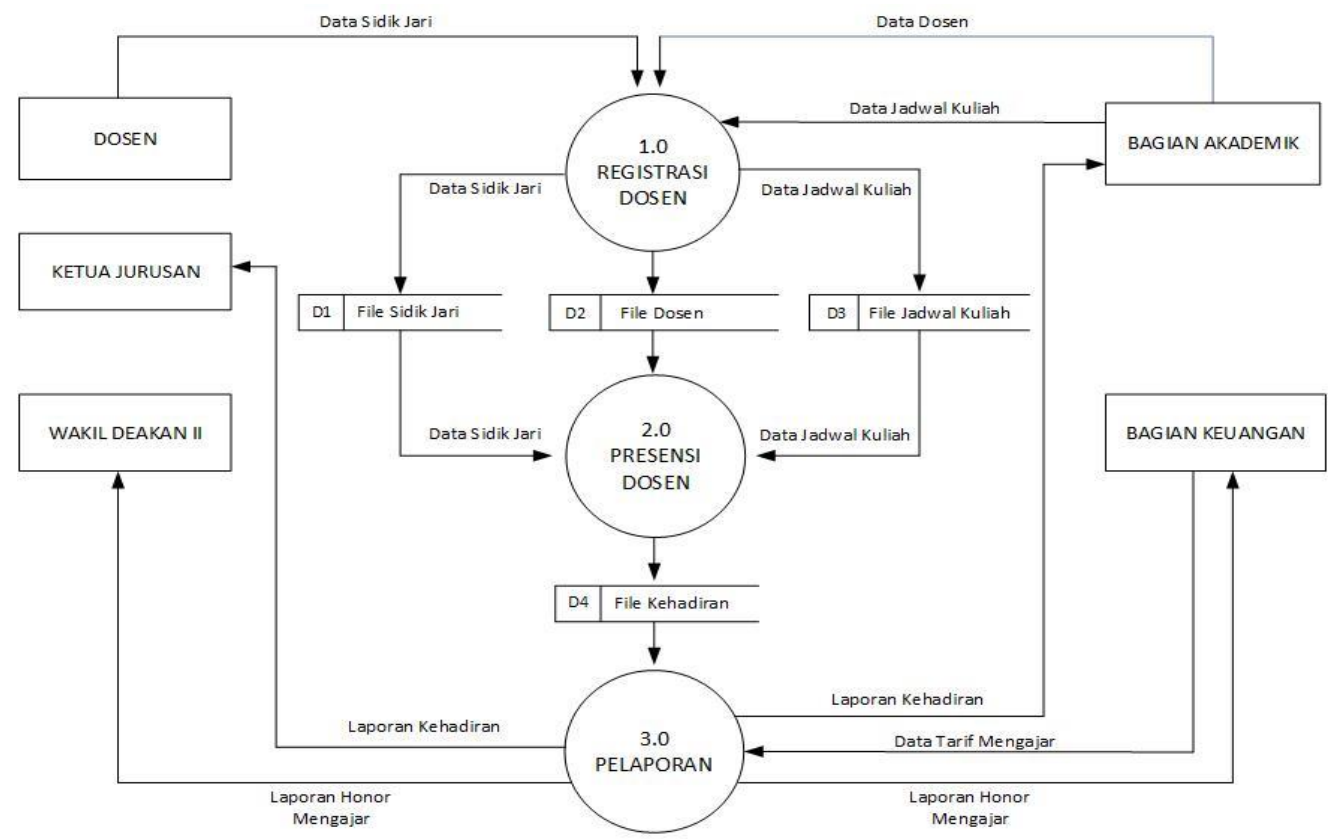

Gambar 5. DFD Level 0

\section{Entity Relationship Diagram (ERD)}

ERD merupakan model data konseptual yang merepresentasikan hubungan antar entitas di dalam database pada suatu sistem. Gambar 6 di bawah ini menggambarkan relasi antar entitas dalam SI-HMD yang akan dibangun. Terdapat beberapa tabel master (master table) yang saling berinteraksi antara lain tabel dosen, sidik jari, dan matakuliah sehingga menghasilkan beberapa tabel anak (child table) antara lain tabel jadwal kuliah, kehadiran, dan honorium .

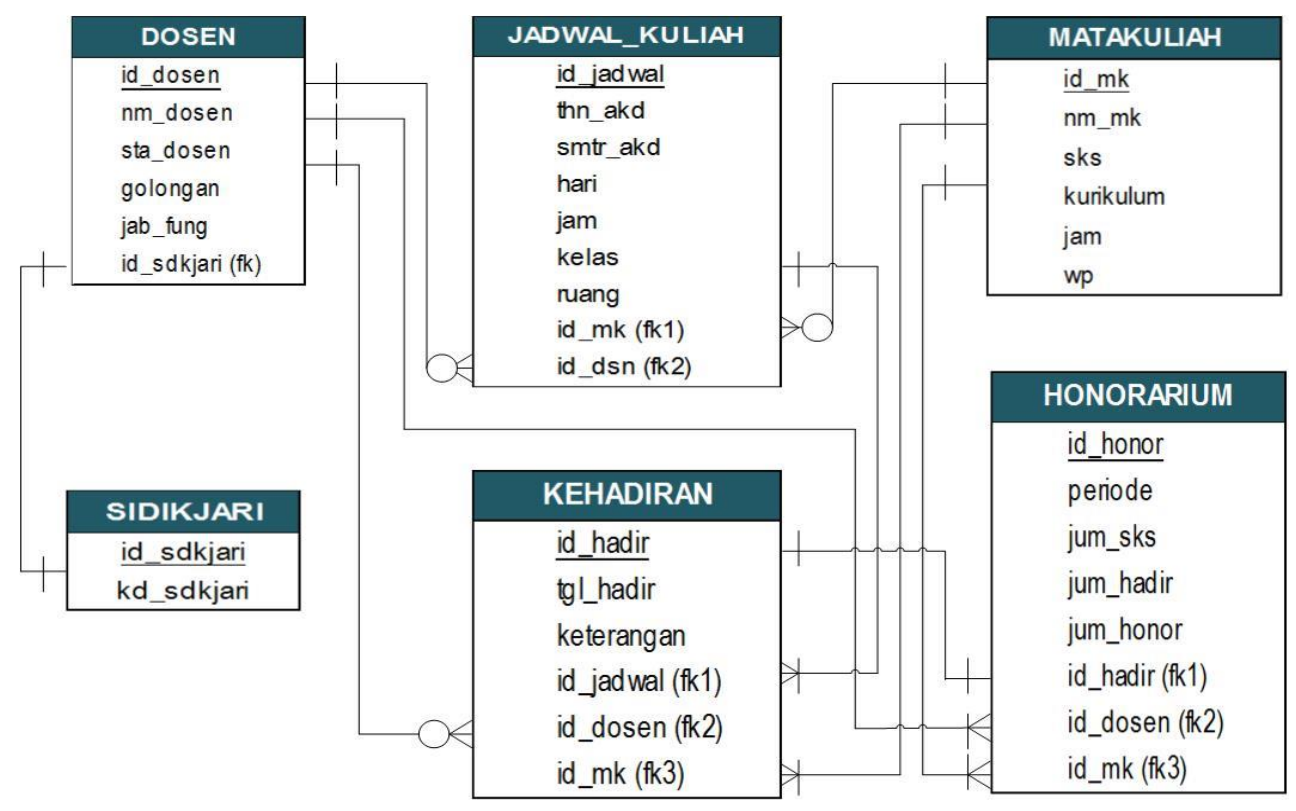

Gambar 6. Entity Relationship Diagram (ERD) 


\section{HASIL PENGEMBANGAN SISTEM}

Hasil pengembangan sistem yang dibangun menggunakan Bahasa Program PHP, Database MySQL, dan teknologi fingerprint dapat dilihat pada gambar di bawah ini. Setiap kali sebelum mengajar dosen wajib melakukan presensi pada scanner fingerprint yang terhubung dengan aplikasi, selanjutnya hasil presensi akan tampil di form presensi seperti pada Gambar 7.

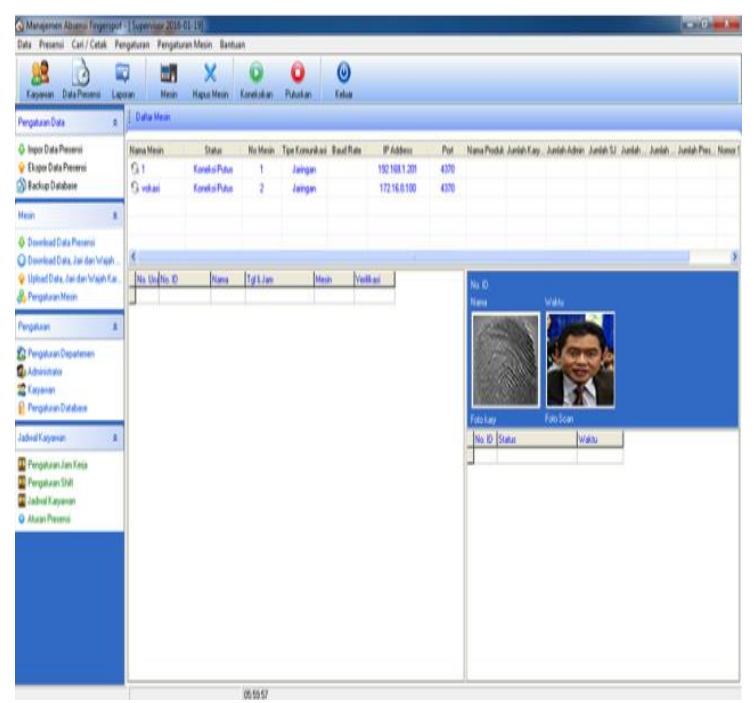

Gambar 7. Form Presensi Mengajar

Berdasarkan data presensi yang dilakukan oleh dosen melalui mesin finger print dapat dipantau daftar kehadiran setiap dosen oleh bagian akademik maupun ketua Jurusan.

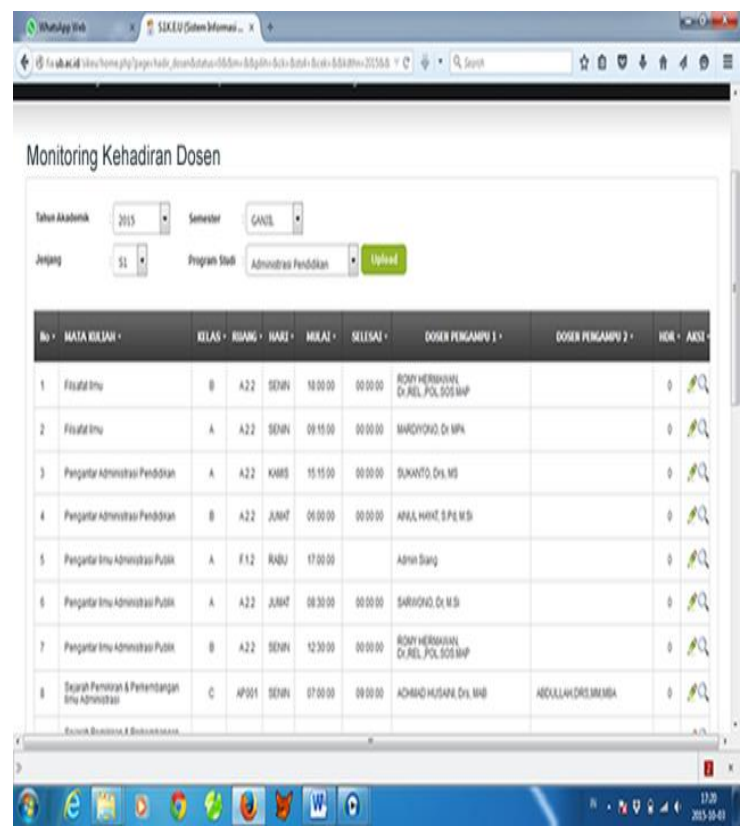

Gambar 8. Laporan Kehadiran Dosen

Selanjutnya dosen maupun wakil dekan dapat mengakses informasi tentang besaran honorarium mengajar dengan report seperti gambar di bawah ini.

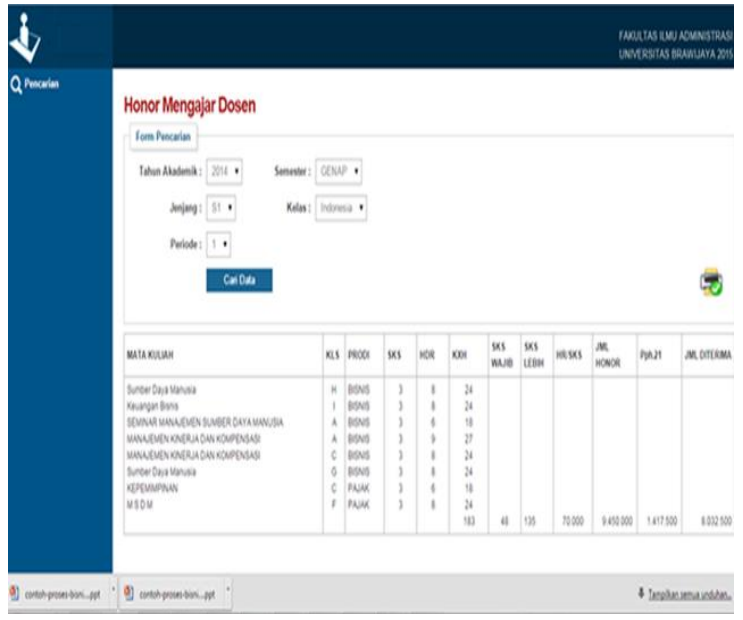

Gambar 9. Informasi Honor Mengajar Dosen

\section{PENGUJIAN SISTEM}

Hasil pengembangan SI-HMD diuji menggunakan metode Response Time, Accuracy Testing, dan Black Box Testing.

\subsection{Pengujian Response Time}

Response time adalah interval waktu yang dibutuhkan oleh sistem untuk merespon request pengguna mulai saat awal mengirimkan perintah, memproses, hingga memberikan feedback ke interface. Pengujian sistem ini dipergunakan untuk menguji response time presensi fingerprint dan akses informasi/laporan honorarium mengajar dosen. 1. Presensi Fingerprint

Uji response time presensi fingerprint dilakukan 3 kali percobaan dengan melibatkan 2 orang operator bagian akademik.

Tabel 3. Hasil Uji Presensi Fingerprint

\begin{tabular}{|c|l|c|c|c|c|}
\hline No & \multicolumn{1}{|c|}{ Proses } & $\mathbf{t}_{1}$ & $\mathbf{t}_{2}$ & $\mathbf{t}_{\mathbf{3}}$ & $\mathbf{t}_{\text {rata }}$ \\
\hline 1 & $\begin{array}{l}\text { Pemindaian } \\
\text { sidik jari }\end{array}$ & 1,10 & 1,08 & 1,07 & 1,08 \\
\hline 2 & $\begin{array}{l}\text { Verifikasi } \\
\text { jadwal kuliah }\end{array}$ & 1,90 & 1,94 & 1,86 & 1,90 \\
\hline & Total & $\mathbf{3 , 0 0}$ & $\mathbf{3 , 0 2}$ & $\mathbf{2 , 9 3}$ & $\mathbf{2 , 9 8}$ \\
\hline
\end{tabular}

Keterangan :

$\mathrm{t}_{1}=$ response time pada percobaan ke-1 (detik)

$\mathrm{t}_{2}=$ response time pada percobaan ke-2 (detik)

$\mathrm{t}_{3}=$ response time pada percobaan ke 3 ( detik)

$\mathrm{t}_{\text {rata }}=$ response time rata-rata (detik)

Tabel 3 menunjukkan bahwa rata-rata response time yang dibutuhkan untuk pemindaian sidik jari dan verifikasi jam hadir dengan jadwal kuliah di database adalah 2,98 detik. 
2. Akses Informasi Honorarium

Uji response time akses informasi honorarium dilakukan 3 kali percobaan melibatkan 2 orang operator bagian keuangan dengan jumlah data sebanyak 64 record terdiri atas :

- dokumen presensi 3 orang dosen

- setiap dosen mengampu 4 matakuliah (asumsi)

- setiap matakuliah 3 sks

- setiap matakuliah maksimal 16 pertemuan

Tabel 4. Hasil Uji Akses Informasi Honorarium

\begin{tabular}{|c|c|c|c|c|}
\hline TIPE SISTEM & $\mathbf{t}_{1}$ & $\mathbf{t}_{\mathbf{2}}$ & $\mathbf{t}_{\mathbf{3}}$ & $\mathbf{t}_{\text {rata }}$ \\
\hline MANUAL & 20,28 & 20,5 & 20,4 & 20,37 \\
\hline SI-HMD & 6,55 & 6,59 & 6,30 & 6,48 \\
\hline
\end{tabular}

Keterangan :

$\mathrm{t}_{1}=$ response time pada percobaan ke- 1 (menit)

$\mathrm{t}_{2}=$ response time pada percobaan ke-2 (menit)

$\mathrm{t}_{3}=$ response time pada percobaan ke-3 (menit)

$\mathrm{t}_{\text {rata }}=$ response time rata-rata (detik)

Tabel 4 menunjukkan bahwa rata-rata response time untuk mengakses informasi honorarium mengajar dosen dengan menggunakan sistem manual membutuhkan waktu 20,37 menit, sementara dengan menggunakan SI-HMD hanya membutuhkan waktu 6,48 menit mulai input presensi fingerprint hingga cetak laporan.

Hasil pengujian response time tersebut di atas menunjukkan bahwa SI-HMD terbukti dapat meningkatkan meningkatkan efisiensi dari aspek waktu pengelolaan honorarium mengajar secara significant. Dari aspek SDM juga lebih efisien karena ketika selesai melakukan presensi fingerprint saat juga dapat dosen bisa mengetahui informasi jumlah kehadiran beserta honor yang akan diterima sehingga tidak memerlukan tenaga khusus rekapitulasi absen. Sedangkan dari aspek prosedur juga dapat memperpendek jalur birokrasi karena hasil proses rekapitulasi kehadiran dan perhitungan honorarium langsung bisa diakses dari sistem tanpa harus melalui bagian unit pelayan kelas, bagian akademik atau pengajaran, dan bagian keuangan.

\subsection{Pengujian Akurasi (Accuracy Testing)}

Tingkat akurasi sistem dapat diukur dari frekuensi kesalahan yang terjadi terhadap jumlah data yang diverifikasi. Semakin rendah frekuensi maka semakin tinggi tingkat akurasi sistem. Pengujian ini melibatkan 2 orang operator bagian keuangan dengan mengambil sample 64 record data terdiri dari dokumen 3 orang dosen yang mengampu 4 matakuliah.
Tabel 5. Hasil Uji Akurasi Honorarium

\begin{tabular}{|c|c|c|c|c|}
\hline $\begin{array}{c}\text { TIPE } \\
\text { SISTEM }\end{array}$ & $\mathbf{f}_{\mathbf{1}}$ & $\mathbf{f}_{\mathbf{2}}$ & $\mathbf{f}_{3}$ & \multicolumn{1}{c|}{ frata } \\
\hline MANUAL & 10,94 & 14,06 & 15,63 & 13,54 \\
\hline SI-HMD & 0,00 & 0,00 & 0,00 & 0,00 \\
\hline
\end{tabular}

Keterangan :

$\mathrm{f}_{1}=$ frekuensi kesalahan pada percobaan ke-1 $(\%)$

$\mathrm{f}_{2}=$ frekuensi kesalahan pada percobaan ke-2 $(\%)$

$\mathrm{f}_{3}=$ frekuensi kesalahan pada percobaan ke-3 $(\%)$

frata=frekuensi kesalahan rata-rata $(\%)$

Hasil pengujian menunjukkan bahwa frekuensi kesalahan rata-rata perhitungan honorarium dengan menggunakan sistem manual sebesar $13,54 \%$ atau memiliki tingkat akurasi $86,46 \%$, sementara dengan menggunakan SI-HMD frekuensi kesalahan sebesar $0,00 \%$ atau memiliki tingkat akurasi $100 \%$, demikian faktor human error dapat diminimalisir.

\subsection{Pengujian Fungsionalitas (BlackBox Testing)}

Black Box Testing adalah pengujian untuk mengetahui apakah semua fungsi perangkat lunak telah berjalan sesuai dengan kebutuhan fugsional yang telah didefinisikan sebelumnya. Pengujian Black Box Testing melibatkan 2 orang operator bagian akademik dan 2 orang operator bagian keuangan memberikan hasil sebagai berikut.

Tabel 6. Hasil Black Box Testing

\begin{tabular}{|c|l|l|c|}
\hline No. & \multicolumn{1}{|c|}{ Fitur } & \multicolumn{1}{|c|}{$\begin{array}{c}\text { Hasil yang } \\
\text { Diharapkan }\end{array}$} & Status \\
\hline 1 & Login & $\begin{array}{l}\text { Hanya user yang } \\
\text { terdaftar di database } \\
\text { yang diijinkan } \\
\text { masuk ke sistem }\end{array}$ & Valid \\
\hline 3 & $\begin{array}{l}\text { Registrasi } \\
\text { Sidikjari } \\
\text { Dosen }\end{array}$ & $\begin{array}{l}\text { Sistem merekam } \\
\text { sidikjari dosen } \\
\text { dengan benar }\end{array}$ & Valid \\
\hline 5 & $\begin{array}{l}\text { Presensi } \\
\text { Fingerprint }\end{array}$ & $\begin{array}{l}\text { Sistem melakukan } \\
\text { verifikasi sidikjari } \\
\text { dan jadwal kuliah } \\
\text { dengan benar }\end{array}$ & Valid \\
\hline 5 & $\begin{array}{l}\text { Cetak } \\
\text { Laporan } \\
\text { Kehadiran }\end{array}$ & $\begin{array}{l}\text { Sistem } \\
\text { menampilkan } \\
\text { laporan kehadiran } \\
\text { dengan benar }\end{array}$ & Valid \\
\hline 6 & $\begin{array}{l}\text { Cetak } \\
\text { Honor } \\
\text { Mengajar }\end{array}$ & $\begin{array}{l}\text { Sistem } \\
\text { menampilkan } \\
\text { laporan honorarium } \\
\text { dengan benar }\end{array}$ & Valid \\
\hline
\end{tabular}




\section{PENUTUP}

\subsection{Kesimpulan}

Berdasarkan hasil pengujian terhadap SI-HMD yang telah dirancang dan dibangun dapat disimpulkan bahwa :

1. Proses presensi, rekapitulasi kehadiran, pembayaran honorarium yang terintegrasi dalam satu sistem dapat meningkatkan efisiensi waktu SDM, dan prosedur dalam pengolalaan honorarium mengajar dosen.

2. Tingkat akurasi perhitungan honorarium mengajar dosen hingga mencapai $100 \%$, dengan demikian faktor human error dapat diminimalisir.

3. Transparansi pengelolaan honorarium mengajar diharapkan dapat ditingkatkan karena sistem telah menyediakan fasilitas kepada dosen untuk mengakses informasi honorarium mengajar..

4. Hasil pengujian sistem menggunakan metode Black Box Testing menunjukkan bahwa semua fitur SI-HMD telah berfungsi dengan baik dan siap diimplementasikan.

\subsection{Saran}

Berikut ini beberapa saran untuk penelitian dan pengembangan sistem lebih lanjut :

1. Pembangunan SI-HMD perlu dintegrasikan dengan sistem informasi kehadiran mahasiswa untuk memudahkan pelaksanaan monitoring perkuliahan.

2. Untuk meningkatkan kedisiplinan mahasiswa sebaiknya dikembangkan sistem informasi kehadiran mahasiswa berbasis sms gateway agar mahasiswa yang absen dapat terlaporkan kepada orang tua mahasiswa.

\section{DAFTAR PUSTAKA.}

Akinduyite, C.O., Adetumbi, C.O., Olabode, O.O., \& Ibidunmoye, E.O. 2013. Fingerprint-Based Attedance Management System. Journal of Computer Sciences and Applications, 1(5), 100-105.

Gemino, A. \& Parker, D. 2009. Use case diagrams in support of use case modeling : Deriving understanding from the picture. Journal of Database Management, 20(1), 1-24.

Indico, M.H. 2016. Development of Employee Attedance and Payroll System Using Fingerprint Biometric. Journal of Computer Science and Software Development, 1(1), 1-12.

Khan, E.M. 2010. Different Forms of Software Testing Techniques for Finding Error. International Journal of Computer Science Issue, 7(1), 1694-0784.

Moertini, V.S., Athur, A.A., Kernit, H.M., \& Saputro, N. 2011. The Development of Electronic Payment System For Universities in Indonesia: on Resolving Key Succes Factors. International Journal of Computer Science and Information Technology, 3(2), 16-33.

Satyawan, A.H., Hariadi, B., \& Ameliah, T. 2013. Sistem Informasi Penggajian Menggunakan Presensi Sidik Jari. Jurnal Sistem Informasi, 2(3), 60-65. 